\title{
Reflexões sobre o trabalho docente
}

Marcia Cristina Corrêa*

\section{Resumo}

O presente artigo propõe uma reflexão sobre o trabalho docente. Para isso, partimos do pressuposto de que a docência é um trabalho. Apesar de parecer uma afirmação óbvia, as pesquisas que analisam as representações do trabalho docente demonstram dificuldades para definir essa profissão e, particularmente, para compreendê-la como um trabalho. Neste artigo, apresentamos as bases do Interacionismo Sociodiscursivo, que é o referencial teórico que utilizamos para a análise do trabalho docente. Essa escolha decorre da importância dada pela teoria ao estudo do papel da prática de linguagem em situações de trabalho, no caso, trabalho docente. Por fim, apresentamos alguns dados decorrentes de uma das ações do Projeto "Representações do Agir docente", que tem por objetivo analisar as representações do agir docente em textos pertinentes à atividade educacional.

Palavras-chave: Ensino como trabalho. Trabalho docente. Interacionismo Sociodiscursivo

\section{Considerações iniciais}

O objetivo deste texto é fomentar a reflexão sobre o trabalho docente. A proposta de reflexão parte de uma breve contextualização das pesquisas sobre o tema desenvolvidas pelo grupo vinculado à Linha de Pesquisa "Linguagem e Interação" do Programa de Pós-graduação em Letras da Universidade Federal de Santa Maria, agregando docentes, alunos da graduação e da pós-graduação (mestrado e doutorado). As ações envolvendo alunos dos diferentes níveis de formação estão ligadas ao projeto guarda-chuva: "Representações do Agir docente". Esse projeto tem como objetivo geral a análise das representações do trabalho docente que estão presentes nos diferentes textos pertinentes à atividade educacional

\footnotetext{
Docente do Programa de Pós-Graduação em Letras, da Universidade Federal de Santa Maria (PPGL-UFSM). Integrante da Linha de Pesquisa Linguagem e Interação. Coordenadora do Projeto "Representações do Agir docente”. Contato: macrisco@gmail.com
} 
(discurso dos professores, dos professores em formação e dos alunos; documentos oficiais, material didático, textos que circulam na mídia).

A concepção de linguagem, que sustenta o projeto e orienta os procedimentos metodológicos, é baseada na perspectiva interacionista. Nesse sentido, a linguagem é vista como lugar de interação e de interlocução, para que, ao mesmo tempo em que constitui os polos da subjetividade e da alteridade, seja constantemente modificada pelo sujeito, que atua sobre ela. Essa concepção permite não só visualizar uma relação dinâmica e constitutiva entre o sujeito e a linguagem, como também voltar a atenção para os sujeitos e suas histórias individuais de relação com a linguagem. Assim, dentro dessa concepção, os papéis de sujeito e de outro na linguagem adquirem relevância e, com isso, passam a interessar os indivíduos que ocupam esses papéis discursivos, em situações reais de interlocução, historicamente situadas.

Em consonância com essa concepção de linguagem, o projeto é embasado nos pressupostos teórico-metodológicos do Interacionismo sociodiscursivo (doravante ISD), de Bronckart e Bronckart e Machado. Essa escolha deve-se ao fato da importância dada pela teoria ao estudo do papel da prática de linguagem (agir discursivo) em situações de trabalho, no caso, trabalho docente. A proposta do ISD é analisar (compreender) as relações entre linguagem e trabalho, especificamente, trabalho docente. Para isso, são propostas questões em busca de respostas que possibilitariam a compreensão dessa relação: a) Como se caracterizam, nos diferentes níveis de textualidade, os diversos textos produzidos no e sobre esse trabalho? b) Quais são as representações e avaliações sobre o agir docente apresentadas nos textos? c) Quais são as representações e avaliações dos elementos constitutivos desse trabalho? Para se chegar às respostas a essas questões, as pesquisas tomam por base a análise de textos orais e escritos produzidos no e sobre o trabalho docente.

No presente texto, situamos o Interacionismo Sociodiscursivo, concentrando-nos na exposição da abordagem empregada para a análise de textos que tematizam o trabalho docente, bem como apresentamos uma discussão acerca do professor como trabalhador.

Na sequência, apresentamos informações referentes a uma das ações do Projeto "Representações do agir docente". $\mathrm{Na}$ pesquisa, propomos acompanhar a turma ingressante em 2011 no primeiro semestre do Curso de Letras - Português - da Universidade Federal de Santa Maria, com o objetivo de acompanhar esses alunos durante o desenvolvimento do Curso, com entrevistas pontuais. Com isso, buscamos estabelecer a (des) construção das representações pertinentes ao agir docente apresentadas por esses sujeitos no decorrer do curso de graduação (formação de professor). Neste artigo, discutiremos alguns pontos relativos à primeira coleta de dados da referida 
pesquisa. Para isso, descreveremos o contexto de produção dos textos coletados, procederemos a uma análise inicial das respostas dadas pelos acadêmicos às perguntas "Por que escolheu o Curso de Letras?" e "O que é ser professor?", visando compreender quais elementos do trabalho do professor são tematizados nas respostas dos acadêmicos.

\section{Referencial teórico}

\section{O Interacionismo Sociodiscursivo: bases teóricas}

O projeto do ISD é caracterizado por uma psicologia que deve considerar as ações humanas em suas dimensões sociais e discursivas constitutivas. Em função disso, como afirma Bronckart, a abordagem do ISD vai além da linguística, caracterizando-se como "ciência integrada do humano, centrada na dinâmica formadora das práticas de linguagem." (2007, p. 20).

De acordo com Bronckart (2007), as principais fontes de inspiração do ISD estariam baseadas em Vigotski; Volochínov e Bakhtin.

Assim, o ISD tomou a tese de Vigotski: a apropriação (interiorização) dos signos de uma língua natural é constitutiva do pensamento humano consciente. Para Vigotski (2001), a linguagem é o ponto nodal para o entendimento do homem como ser histórico e social, cuja compreensão deve ser buscada por meio do cruzamento das perspectivas individual e histórica. Esse pressuposto de Vigotski decorre do Materialismo Histórico (Marx e Engels), que entende que: a) o modo de produção da vida material condiciona a vida social, política e espiritual do homem; b) o homem é um ser histórico, que se constrói a partir de suas relações com o mundo natural e social. Em função disso, o processo de trabalho - transformação da natureza - é o processo privilegiado nessas relações homem-mundo.

De Volochínov (BAKHTIN/VOLOCHÍNOV, 1978), o ISD tomou a abordagem descendente dos fatos linguageiros, colocando em primeiro plano a práxis, isto é, a dimensão ativa, prática, das condutas humanas em geral e das condutas verbais em particular. Na obra Marxismo e filosofia da linguagem, o projeto era clarificar as condições de constituição do pensamento consciente humano, no quadro de uma pesquisa que focalizaria: a) As condições e os processos de interação social: em termos contemporâneos, as diversas redes e formas da atividade humana; b) as formas de enunciação, que verbalizam ou semiotizam essas interações sociais no quadro de uma língua natural; c) a organização dos signos no interior dessas formas, que, segundo o autor, seriam constitutivos das ideias e do pensamento humano consciente.

De Bakhtin, o ISD tomou a noção de gêneros do discurso. Bakhtin (1992) mostrou a dependência dos gêneros em relação aos tipos de atividade humana, distinguindo os gêneros primários e os gêneros secundários. Além disso, descreveu e analisou diversas propriedades dos 
gêneros, dentre as quais seu caráter fundamentalmente interativo ou dialógico.

A partir dessas bases epistemológicas, Bronckart afirma que o ISD parte de premissas do interacionismo social, corrente geral da filosofia e das ciências humanas. Assim considera que "as propriedades específicas das condutas humanas são resultado de um processo histórico de socialização, possibilitado especialmente pela emergência e pelo desenvolvimento dos instrumentos semióticos" (1999, p. 21). A partir dessa afirmação, fica evidente à filiação ao pensamento de Vigotski, especialmente no que tange aos postulados marxistas (noção de instrumento em termos físicos - filogênese - e também em nível psicológico - ontogênese), bem como à noção de internalização, tão cara à teoria vigotskiana.

A partir do conceito de atividade de Leontiev, Bronckart (1999) defende que, na espécie humana, a cooperação dos indivíduos nas atividades coletivas é regulada e mediada por verdadeiras interações verbais, sendo elas que conferem o estatuto "social" das atividades coletivas. Em função disso, para facilitar a realização das tarefas, a criação de instrumentos desencadeou na utilização de produções sonoras decorrentes da necessidade de acordo. Isso, por sua vez, levou os seres humanos, no curso de sua evolução, à constante negociação de significados, a fim de que a comunicação se estabelecesse.
Para embasar essa ideia, Bronckart retoma o princípio saussuriano da arbitrariedade do signo linguístico: a fim de que se tenha êxito na realização das tarefas, é necessário o compartilhamento de unidades comuns aos falantes (os signos). Se o signo não fosse convencional, arbitrário, não haveria entendimento entre os humanos e com isso, consequentemente, não haveria interação. Esse postulado saussuriano é considerado fundamental para o ISD.

Nesse sentido, para o ISD é central a noção de agir. A atuação do ser humano se dá de modo cooperativo, ou seja, os indivíduos cooperam uns com os outros na atividade, a qual ocorre em constante interação social, sendo mediada pela linguagem. Essa atividade de interação é definida por Habermas (1989), como agir comunicativo.

$\mathrm{O}$ agir comunicativo considera que as representações são como signos, isto é, funcionam como representações comuns, compartilháveis e comunicáveis. Esses signos são caracterizados pela dimensão transindividual, ou seja, a compreensão linguística de todos os membros de uma comunidade, veiculando as representações coletivas do meio, que se estruturam em configurações de conhecimentos chamados por Habermas de mundos representados, divididos em mundo objetivo, mundo social e mundo subjetivo.

As ações humanas, de acordo com Bronckart (1999), realizam-se, portanto, nesses mundos, carregando, no interior deles, pretensões à validade, desdobra- 
das em pretensão à verdade, relativa ao mundo objetivo; à eficácia, no mundo social; e à autenticidade, no mundo subjetivo. Tais ações, verbalizadas na atividade de linguagem, produtos de atividade social desempenhada por indivíduos particulares, são também objeto de avaliações sociais, isto é, tornam-se parâmetros a partir dos quais cada indivíduo julga a validade do agir de seus pares em relação aos mundos representados. Esse processo de avaliação, calcado em permanentes negociações, é o que confere aos indivíduos o estatuto de agentes.

Para o ISD, a chamada atividade de linguagem envolve, inevitavelmente, alguma forma de semiotização, que se dá por meio de textos, os quais, por sua vez, ancoram-se em gêneros (conforme a acepção de Bakhtin). O texto é, portanto, uma unidade central para o ISD, haja vista que, ao mesmo tempo em que é capaz de revelar as representações dos agentes, tem o poder de incidir sobre essas representações.

\section{O Interacionismo Sociodiscursivo: o texto como objeto de análise}

No Brasil, muitas pesquisas embasadas no ISD tomam como objeto de análise de textos produzidos no e sobre o trabalho docente. Esses estudos partem do seguinte pressuposto do ISD (BRONCART, 2006): as ações humanas não podem ser apreendidas pela mera observação das condutas perceptíveis, mas por meio de interpretações produzidas via linguagem, em textos dos próprios actantes ou de observadores dessas ações.

Esses textos, referentes à determinada atividade social, não apenas exercem influência sobre essa atividade e sobre as ações nela implicadas, como também refletem representações, interpretações e avaliações sociais sobre essa atividade e sobre essas ações.

Assim, segundo Machado et al., esses textos podem "contribuir para a consolidação e para a modificação dessas mesmas representações e das próprias atividades e ações" (2009, p. 18). Para as autoras, tal premissa implica, no caso da observação da atividade educacional, que sejam tomados como objeto de análise "os textos que se desenvolvem, tanto $n a$ própria situação de trabalho quanto os que se desenvolvem em outros momentos, sobre essa atividade profissional" (2009, p. 18).

Nessa perspectiva, os textos analisados podem ter sido produzidos durante a própria situação de trabalho, em uma dinâmica de interação (no caso, geralmente, professor-aluno); como também advirem de documentos prescritivos do trabalho (educacional), ou então serem originários do próprio trabalhador (professor), sejam produções que ele escreve com relação ao seu próprio trabalho, sejam textos referentes ao seu planejamento. Há ainda uma terceira configuração textual passível de análise: trata-se de textos descritivos/interpretativos/ 
avaliativos produzidos por observadores externos depois da realização de uma determinada tarefa (diários de aula, relatórios de estágio, etc.) ou pelo próprio trabalhador (qualquer texto produzido por indução do pesquisador sobre o trabalho realizado).

Em relação à análise dos textos sobre o trabalho docente, Machado e Bronckart (2009) propõem que o ponto de partida seja a identificação do contexto de produção dos textos. Feito isso, em seguida, inicia-se a análise dos textos, considerando-os em três níveis: organizacional, enunciativo e semântico.

Quanto ao nível organizacional dos textos, a análise deve considerar a identificação do plano geral dos textos e das sequências; a identificação dos tipos de discursos mobilizados e de sua articulação, bem como os mecanismos de coesão nominal e de conexão.

No nível enunciativo do texto, devem ser considerados os mecanismos de responsabilização enunciativa, tais como: marcas de pessoa; índices de inserção de vozes; modalizadores do enunciado; bem como outras marcas que indiquem subjetividade.

Com relação ao nível semântico, engloba considerações referentes aos níveis anteriores, chegando-se às interpretações. No tocante ao nível semântico, de acordo com Machado e Bronckart (2009), também é possível realizar análises no nível mais micro, para responder a questões de pesquisa específicas. No caso da amostra de análise apresentada nesse artigo, essa tem por objetivo responder às questões: Que elementos do trabalho/ agir do professor são tematizados nas respostas dos acadêmicos.

Nesse sentido, em nossos dados, analisamos os predicados que (de modo direto ou indireto) têm como sujeito o "professor", observando, especialmente, o verbo que predica este sujeito, bem como também algumas nominalizações. Para classificar os verbos e nominalizações que codificam o agir do professor, consideramos categorizações desenvolvidas/retomadas por Mazzillo (2006) e Barricelli (2007), as quais já foram eficientemente utilizadas no trabalho de Barbosa (2009).

Para a melhor compreensão do leitor, tais categorias são apresentadas, com exemplos, no quadro abaixo: 
Quadro 1: Formas de agir tematizadas em textos sobre o trabalho do professor

\begin{tabular}{|c|c|c|}
\hline Categoria & Definição & $\begin{array}{c}\text { Exemplos } \\
\text { (retirados dos dados do Projeto } \\
\text { "Representações do Agir docente") }\end{array}$ \\
\hline $\begin{array}{l}\text { Agir com } \\
\text { instrumentos }\end{array}$ & $\begin{array}{l}\text { Predicados que representam um } \\
\text { agir individual do professor com o } \\
\text { uso de instrumentos (simbólicos ou } \\
\text { materiais). }\end{array}$ & $\begin{array}{l}\text { (Ser professor) é utilizar os } \\
\text { teus conhecimentos a favor do } \\
\text { crescimento de outras pessoas. } \\
\text { (agir com instrumento simbólico) }\end{array}$ \\
\hline $\begin{array}{l}\text { Agir mental/ } \\
\text { cognitivo }\end{array}$ & $\begin{array}{l}\text { Predicados que indicam atividade } \\
\text { mental ou capacidade do professor. }\end{array}$ & Ele não sabe de tudo. \\
\hline Agir linguageiro & $\begin{array}{l}\text { Predicados com verbos de dizer. } \\
\text { Podem ser de três tipos: a) agir } \\
\text { linguageiro que implica uma resposta } \\
\text { imediata dos alunos; b) não implica } \\
\text { uma resposta imediata dos alunos; } \\
\text { c) agir linguageiro do professor em } \\
\text { reação ao agir dos alunos. }\end{array}$ & $\begin{array}{l}\text { O professor tem que explicar o } \\
\text { conteúdo. } \\
\text { (agir linguageiro do tipo b) }\end{array}$ \\
\hline Agir afetivo & $\begin{array}{l}\text { Predicados que implicam em um agir } \\
\text { emocional. }\end{array}$ & $\begin{array}{l}\text { Eu acho que começa tu [o } \\
\text { professor] gostando do que tu faz. }\end{array}$ \\
\hline $\begin{array}{l}\text { Agir físico/ } \\
\text { corporal }\end{array}$ & $\begin{array}{l}\text { Predicados com verbos que implicam } \\
\text { em um agir físico, relacionado a um } \\
\text { movimento corporal. }\end{array}$ & O professor entra na sala. \\
\hline $\begin{array}{l}\text { Agir } \\
\text { pluridimensional }\end{array}$ & $\begin{array}{l}\text { Predicados que envolvem um agir } \\
\text { que engloba mais de uma forma de } \\
\text { agir. }\end{array}$ & $\begin{array}{l}\text { Tu [o professor] vai ensinar as } \\
\text { pessoas. }\end{array}$ \\
\hline
\end{tabular}

Fonte: Organizado a partir de Mazzillo (2006), Barricelli (2007), Barbosa (2009), Muniz-Oliveira (2011) e adaptada por Corrêa e Veçossi (2012).

\section{O Interacionismo Sociodiscursivo: análise do trabalho docente}

\section{Em função dos pressupostos marxis-} tas (basilares para as ideias de Vigotski, Volochinov e Bakhtin), o ISD considera central discutir a importância do trabalho, tanto para o desenvolvimento da espécie quanto do indivíduo. Nesse sentido, Bronckart define que:
O trabalho se constitui, claramente, como um tipo de atividade ou de prática. Mas, mais precisamente, é um tipo de atividade própria da espécie humana, que decorre do surgimento, desde o início da história da humanidade, de formas de organização coletiva destinadas a assegurar a sobrevivência econômica dos membros de um grupo: tarefas diversas são distribuídas entre esses membros (o que se chama de divisão do trabalho); assim, esses membros se veem com papéis e responsabilidades específicas a eles atribuídos, e a efetivação do controle dessa organização se traduz, necessariamente, pelo estabelecimento de uma hierarquia (2006, p. 209). 
Conforme Machado (2007), tal definição é insuficiente para que se compreenda o trabalho do professor. De acordo com a autora, para que se chegue a tal definição, é necessário agregar concepções oriundas das Ciências do Trabalho, principalmente, da Ergonomia da Atividade (AMIGUES, 2004) e da Clínica da Atividade (CLOT, 2007, 2010). Essas concepções só passaram a ser discutidas em função de mudanças históricas as quais levaram a considerar o trabalho intelectual, que não resulta em bens materiais - como o do professor -, como fonte de estudo (surgimento da "prestação de serviços"). Nesse sentido, o trabalho do "prestador de serviços" passou a ser alvo de prescrições, as quais enfatizavam a necessidade de comunicação destes trabalhadores, o que impulsionou o surgimento de pesquisas ancoradas em abordagens linguísticas.

Machado afirma ainda que, somente a partir da década de 1990, o trabalho dos professores passou a ser objeto de pesquisas. Isso aconteceu, especialmente, em função de que os sistemas educacionais começaram a implementar uma lógica de mercado, "apregoando-se a necessidade da constituição de um novo profissional do ensino" (2007, p. 88). Esse fato, ao tentar impor uma lógica neoliberal ao agir do professor, trouxe sérias consequências sobre a subjetividade e a identidade desse profissional. Foi nesse contexto que a abordagem ergonômica passou a ser empregada, como, segundo Machado, "um instrumento adequado para enfocar a complexidade da atividade educacional enquanto trabalho e o real funcionamento do professor enquanto trabalhador" (2007, p. 90).

Visando à construção de uma definição contemporânea de trabalho docente (de base marxista), Machado e Bronckart (2009), a partir dos trabalhos das Ciências do trabalho, propõem as seguintes características para tal atividade:

a) é pessoal e sempre única, envolvendo a totalidade das dimensões do trabalhador (físicas, mentais, práticas, emocionais etc.);

b) é plenamente interacional, já que, ao agir sobre o meio, o trabalhador $o$ transforma e é por ele transformado;

c) é mediada por instrumentos materiais ou simbólicos;

d) é interpessoal, pois envolve sempre uma interação com outrem (todos os outros indivíduos envolvidos direta ou indiretamente, presentes ou ausentes, todos os "outros" interiorizados pelo sujeito);

e) é impessoal, dado que as tarefas são prescritas ou prefiguradas por instâncias externas;

f) é transpessoal, no sentido de que é guiada por "modelos do agir" específicos de cada métier.

Quanto ao trabalho do professor, especialmente no que tange à realização deste fazer em determinada sala de aula, Machado afirma que, embora esse atinja o profissional como um todo (o seu ser integral), em situações dentro e fora da sala de aula, apresenta como objetivo: 
[...] criar um meio que possibilite aos alunos a aprendizagem de um conjunto de conteúdos de sua disciplina e o desenvolvimento de capacidades específicas relacionadas a esses conteúdos, orientando-se por um projeto de ensino que lhe é prescrito por diferentes instâncias superiores e com a utilização de instrumentos obtidos do meio social e na interação com diferentes outros que, de forma direta ou indireta, estão envolvidos na situação (2007, p. 93).

Desse modo, a primeira parte da definição apresentada pela autora situa o professor no interior de sua disciplina como alguém que cria meios para a aprendizagem de conteúdos e para 0 desenvolvimento de capacidades a eles relacionadas.

A partir da retomada teórica sobre o trabalho do professor, por certo, paira ainda a pergunta: afinal, por que analisar o trabalho do(a) professor(a) - trabalho docente? Uma das justificativas talvez esteja nas palavras de Bronckart que:

[...] apresenta alguns resultados de pesquisas sobre o trabalho do professor, os quais evidenciam claramente a especificidade desse trabalho e, sobretudo, a sua relativa opacidade, isto é, a dificuldade de descrevê-lo, caracterizá-lo e, até mesmo, de simplesmente falar dele (2006, p. 203-204).

Ao reconhecermos e, principalmente, concordarmos com a afirmação de Bronckart, tomamos o trabalho docente - do licenciado em Letras - como objeto de pesquisa. Assim, nas diferentes ações do Projeto "Representações do agir docente", buscamos delinear a especificidade desse trabalho e entender a referida opacidade na descrição ou caracterização dessa atividade por parte dos atores principais: os professores e os professores em formação. No presente texto, apresentaremos uma discussão a partir da fala de professores em formação: alunos do curso de Letras (habilitação Língua Portuguesa).

\section{As representações do agir docente no discurso dos alunos de Letras}

O projeto "As representações do agir docente" teve início no ano de 2011 e, de acordo com o cronograma traçado, chegará ao fim somente em 2014. Considerando que a investigação tem como uma das ações acompanhar e analisar as representações do agir docente presente nos textos pertinentes à atividade educacional no discurso de alunos do Curso de Letras no decorrer de sua graduação, o projeto prevê quatro coletas, cada uma delas realizada em início de semestre, situadas em momentos-chave da formação acadêmica dos estudantes, conforme se pode visualizar no quadro apresentado a seguir.

Quadro 2: Cronograma das Coletas

\begin{tabular}{|l|l|l|}
\hline $1^{\text {a }}$ coleta & $1^{\text {o }}$ semestre & Início do Curso. \\
$2^{\text {a }}$ coleta & $3^{\circ}$ semestre & Período anterior às disciplinas de didática e estágio. \\
$3^{\text {a }}$ coleta & $5^{\text {o }}$ semestre & Período posterior às disciplinas didáticas, mas anterior ao estágio. \\
$4^{\text {a }}$ coleta & $8^{\circ}$ semestre & Período posterior ao estágio supervisionado. \\
\hline
\end{tabular}


Neste texto, discutiremos dados referentes à (primeira) coleta realizada no primeiro semestre do Curso, em março de 2011, com os alunos que recém haviam sido aprovados para o Curso de Licenciatura em Letras - Português e Literaturas de Língua Portuguesa. Como critério de escolha dos sujeitos, consideraram-se apenas os que vieram direto do Ensino Médio para o Ensino Superior, por meio do Vestibular ou outro modo de seleção. Assim, chegou-se ao número de 28 sujeitos, sendo 26 do sexo feminino e dois do sexo masculino, todos na faixa etária dos 17 aos 21 anos.

A metodologia adotada no projeto toma como instrumento a entrevista semi-estruturada, a partir de tópicos sobre o agir docente. As entrevistas foram gravadas em áudio e depois transcritas (com base no Projeto Nurc Projeto de Estudo da Norma Linguística Urbana Culta/USP/SP). As entrevistas desenvolveram-se a partir das seguintes perguntas:

1) Por que escolheu o Curso de Letras?

2) Quais são as expectativas em relação ao curso?

3) Quer ser professor?

4) O que é ser professor?

5) Lembra de um professor que tenha sido marcante?

6) Como projeta a atuação profissional?

Cabe destacar que, na prática da realização das entrevistas, essas perguntas foram propostas aos entrevistados como tópicos para discussão e, portanto, nem sempre foram apresentadas na ordem dada.
Neste artigo, focaremos nas respostas apresentadas pelos alunos para a primeira e quarta pergunta. Em relação à primeira, (Por que escolheu o Curso de Letras?), buscaremos traçar um perfil do grupo de alunos ingressantes no Curso de Letras. Em relação à quarta pergunta $(\mathrm{O}$ que é ser professor?), faremos uma análise das formas de agir mobilizadas nas falas dos acadêmicos, permitindo uma reflexão inicial com relação a possíveis representações do agir docente expressas por esses professores em formação

Antes de apresentarmos a descrição e análise das respostas, convém, sendo coerentes com a metodologia do ISD, explicitarmos a situação de ação de linguagem na qual ocorreu a coleta de dados.

\section{Contexto de produção dos textos}

\section{Para Bronckart,}

[...] o agente que vai produzir um novo texto se encontra em uma situação de ação de linguagem. Mas essa situação só é operante pelas representações que o agente construiu para si mesmo [...] (2006, p. 146).

$\mathrm{O}$ autor aponta que essas representações podem ser agrupadas da seguinte maneira: a) representações referentes ao quadro material ou físico da ação; b) representações referentes ao quadro sociossubjetivo da ação verbal; c) outras representações referentes à situação e também os conhecimentos disponíveis no agente, referentes à temática que será expressa no texto. A seguir, descrevemos 
a situação de ação de linguagem na qual se encontram os sujeitos de nosso estudo.

Com relação às representações referentes ao quadro material ou físico da ação, ou seja, o contexto físico no qual se deu a coleta de dados, cabe considerar lugar e momento da produção e também quem são os participantes da situação. Assim, o lugar de produção é a própria instiuição de ensino superior na qual ocorreu a coleta, em uma sala de aula. O momento da produção corresponde ao momento da entrevista, realizada em horário de aula. Quanto aos participantes, as posições de emissor e receptor foram assumidas, respectivamente, pelo acadêmico do Curso de Letras que concedeu a entrevista e pelo pesquisador, também acadêmico, participante do projeto, que fazia as perguntas, sendo considerado, portanto, um co-produtor do texto produzido.

Quanto ao contexto sociossubjetivo, é preciso considerar o tipo de interação, os papéis sociais do emissor e do receptor, bem como as relações de objetivo. O tipo de interação compreende uma entrevista realizada no espaço acadêmico. Aparentemente, trata-se de uma interação simétrica, uma vez que ambos os agentes - tanto o entrevistado quanto o entrevistador - são acadêmicos de um curso de graduação. No entanto, o acadêmico que concede a entrevista tem ciência de que se trata de uma situação de pesquisa, na qual o conteúdo da conversa está sendo gravado, e, posteriormente, será descrito e analisado, fato que impõe uma situação de assimietria na interação. No que tange aos papéis sociais, o emissor é um acadêmico do Curso de Letras que recém ingressou no meio universitário; já o receptor, também acadêmico, é integrante de um grupo de pesquisa. Quanto às relações de objetivo, para ambos os agentes trata-se de uma situação de pesquisa.

No que diz respeito ao conteúdo temático, ou seja, os conhecimentos referentes aos temas apresentados nos textos, consideramos, a partir do gênero entrevista, que a interação envolve os os tópicos "escolha do curso de letras" e "definição sobre ser professor".

\section{Por que escolheu o Curso de Letras?}

Com o objetivo de traçar o perfil dos alunos ingressantes no Curso de Licenciatura em Letras - Língua Portuguesa, vamos apresentar o que esses acadêmicos disseram sobre os motivos que os levaram a escolher esse curso.

$\mathrm{Na}$ primeira coleta de dados, no primeiro semestre de 2001, tivemos a participação de 28 alunos. As respostas dadas referentes à primeira pergunta (tópico apresentado) apresentada - Por que escolheu o Curso de Letras? - foram assim categorizadas: Impossibilidade de ingressar no curso desejado (32\%); Interesse pela área (29\%); Desejo de ser professor (21\%); Por eliminação (7\%); Influência de um professor marcante (7\%) e Influência familiar (4\%). 
Na sequência, apresentaremos excertos das respostas dos alunos características das categorias mais significativas para a análise do perfil da turma ingressante: Impossibilidade de ingressar no curso desejado; Interesse pela área; Desejo de ser professor. Esclarecemos que, na transcrição, $\mathrm{P}$ significa pesquisador, responsável pela entrevista, e A, acadêmico, entrevistado.

1) Impossibilidade de ingressar no curso desejado:

Exemplo 1:

$\mathrm{P}$ - Então como é que tu chegou até aqui... no curso de Letras?

A - Ah eu fiz o ensino médio... e eu não sabia ainda bem o que eu queria... eu sabia que eu queria Direito... aí chegou na hora eu não fiz Direito né... eu acabei fazendo::: -- descobri que eu queria Jornalismo... aí eu não consegui passar em Jornalismo aqui na Federal/nem tentei pra te falar a verdade porque:: eu não ia perder minha vaga na federal pra uma coisa que eu não tinha como entrar... (Acadêmico 4)

Exemplo 2:

$\mathrm{P}$ - E quando que tu decidiu fazer o vestibular pra Letras?

A - na verdade... no terceiro ano... que eu tava tentando Direito e:: como não deu pelo PEIES Direito eu tentei algo que eu ia utilizar depois né... (Acadêmico 8)

Exemplo 3:

$\mathrm{P}$ - e quando que tu decidiu fazer o vestibular pra Letras?
A - quando tava no finalzinho das inscrições... ((risos))

$\mathrm{P}$ - é? ((risos)) e por que que tu decidiu fazer o vestibular?

A - pra Letras? no início eu queria fazer pra jornalismo... só que aí... como era bem concorrido... eu olhei assim/eu achei que não tinha muita capacidade de consegui sabe... aí eu fui olhando... fui descartando... fui deixando os que eu/que eu pensava em fazer... daí Letras eu até conversei com meu professor que era/que era o mesmo de português e literatura... daí ela também me estimulou a fazer... que eu ia bem sempre... e eu gostava... eu tinha sempre vontade... eu acho muito bonito... tipo... profissão de professor sabe... mas muita gente vinha me dizer... AH... que não vai ganhar bem... por que:: não vai ser bem remunerada... essas coisas que desanimam... mas daí eu/eu quando me inscrevi era a ideia de eu trocar depois pra jornalismo... mas agora já mudei... agora não quero mais... (Acadêmico 3)

Exemplo 4:

P- é... nunca pensou em fazer outra coisa?

A - eu pra falar a verdade eu queria Direito...

$\mathrm{P}$ - aham...

A - mas::.... como eu sabia que eu não ia ter condições de passar no meu primeiro vestibular... pra Direito eu optei por Letras porque é uma coisa que... eu gosto que eu sempre gostei era a matéria que eu ia melhor no colégio... e eu sou apaixonada por gramática... então... foi por isso que eu... escolhi Letras (Acadêmico 18) 
A categoria "Impossibilidade de ingressar no curso desejado", quantitativamente, é a maior, uma vez que agrega $32 \%$ das respostas dos ingressantes. Com isso, temos um quadro bastante significativo do perfil da turma em análise. Nas passagens apresentadas, representativas dessa categoria, temos claramente expresso pelos alunos que a Licenciatura em Letras não foi a primeira opção. Nesse aspecto, o que chama a atenção são os motivos arrolados pelos alunos para justificar a sua escolha: o primeiro ponto que destacamos é referente à incapacidade de passar no vestibular para o curso desejado, em alguns casos, sem nem ao menos tentar o vestibular, já partindo do pressuposto que não conseguiria a vaga. Assim, podemos inferir que a autoestima desse aluno que ingressa no curso de letras é bem baixa, pois tem como base uma negação: está nesse curso porque entende que não tem competência/ capacidade para cursar outro (o desejado). O segundo ponto que destacamos é relacionado à questão do ingresso em uma universidade pública, independente do curso, o importante é ingressar na universidade federal, e passa, assim, a ser um dos principais desencadeadores para a escolha. Com isso, acaba optando por um curso com um baixo número de candidatos por vaga - Letras é um deles.

2) Interesse pela área

\section{Exemplo 1}

P - uhum... e:.... quando que tu decidiu fazer o vestibular... pra Letras?
A - segundo ano... Foi por causa da/ do conteúdo:: de literatura... parte do romantismo... foi aí onde me apaixonei e decidi fazer Letras... por causa de literatura...

P- especialmente literatura..

A - uhum... (Acadêmico 7)

Exemplo 2:

P - tu::: escolheu Letras por quê?

A - bom... eu escolhi Letras porque eu sempre tive uma facilidade ( ) e eu gostava muito de le:::r e gostava muito de literatura... foi mais por isso (S23)

Exemplo 3:

$\mathrm{P}$ - e quando é que tu decidiu fazer vestibular para Letras?

A - pra Letras... eu decidi foi no... segundo pro terceiro ano já... eu sempre quis fazer alguma coisa ligado... à... à língua né e tal... aí quando eu conheci a literatura mais assim no... no ensino médio eu falei não... quero fazer alguma coisa ligada à língua $\mathrm{E}$ à Literatura... aí procurei saber... procurei me informar... e escolhi por Letras

$\mathrm{P}$ - aham... então tu quis Letras por causa da Literatura mais

A - da literatura... mais do que a língua ((risos)) (Acadêmico 25)

Exemplo 4:

$\mathrm{P}$ - então... me conta um pouquinho.. como é que tu chegou até o curso de Letras... o que que te levou a tá aqui... por que que tá aqui?

A - bom... eu sempre... tive muita facilidade com o Português... com a gra- 
mática... sou muito de corrigir erros de português eu... é muito fácil pra mim Português... e também sô aPAIxonada por lê... por Literatura... e assim... desde pequena assim... eu não era a melhor aluna de Português mas eu sempre fui apaixonada por Literatura assim... os melhores professores -- as aulas que eu mais gostava era isso então... e eu escrevo MUIto... eu gosto muito de escrever... então não teria outra forma... outro lugar mais apropriado do que fazer Letras né... mesmo que eu não queira ser professora... que no caso eu quero pra escrever... pra ser escritora tentar... (Acadêmico 26)

A categoria "Interesse pela área", quantitativamente, é a segunda categoria, agregando $29 \%$ das respostas dos ingressantes. Nas respostas apresentadas, há uma referência direta do interesse dos alunos por assuntos/temas específicos da área de Letras, como, por exemplo, literatura e língua (gramática). Por se tratar de uma turma de alunos do Curso de Letras, consideramos esse ponto muito importante, afinal, faz parte da formação de um licenciado em Letras o interesse pelos tópicos assinalados. Entretanto, pressupomos que, para o licenciado em letras, não basta somente ter o interesse ou gostar de determinada área, mas é necessário o domínio das competências pertinentes a elas, o que só irá se confirmar na sequência do curso. Além disso, o licenciado de letras está em um curso de formação de professores e, em função disso, deveria ter em mente que, ao final do seu curso, deveria estar apto para não só lidar individualmente com esses conhecimentos, mas sim tomá-los como objeto de ensino. Esperamos, enfim, que, ao longo do curso, esse ciclo se conclua e o aluno continue gostando dessas áreas, mas demonstre domínio e, principalmente, venha a ter segurança para ensinar.

\section{3) Desejo de ser professor}

Exemplo 1:

P - uhm... e:: quando que tu decidiu fazer $0::$ vestibular pra Letras?

A - ai... faz muito tempo... desde criança era o que eu queria... é:: sempre foi...

$\mathrm{P}$ - e por que tu te inscreveu no vestibular de Letras?

A - ah:.... por que eu achei que eu fosse ter uma facilidade... agora até... até... eu mudei de opinião... por que... como eu fiz magistério... eu pensei... bah:.... vou mudar pra pedagogia por que aqui no curso... como eu to fazendo estágio do:: do magistério de manhã... daí fica bem puxado... tem que... tem que ler bastante... tem que ter esse ( ) não ter aquele... eu não posso me perder... por que principalmente aquela parte gramatical tu tem que te::... tem que tá atento né... e eu nunca consigo tá atenta... (Acadêmico 9)

Exemplo 2:

P - tá e tu escolheu porque... Letras?

A - olha eu não sei explicar... porque... porque DESde que eu sou criança eu quero ser professora de português... é uma coisa que já veio comigo desde que sou pequenininha... eu tinha um quadro... eu tinha giz... eu dava aula 
pra minhas bonecas desde pequenininha sabe...

P - uhum

A - e meus pais nunca deram muita bola porque acharam que toda/todas crianças brincam né ai de professora e tal... mas eu sempre quis...

P - uhum...

A - e daí::..... eu não tinha uma pontuação muito grande hã::: pr/peloPEIES né

$\mathrm{P}$ - tu é daqui de Santa Maria?

A - não... sô de [...] i... daí eu acabei colocando::: no PEIES Letras e Psicologia também é uma área que me inter/ que me interessava assim sabe... acho interessante... e daí eu fiz vestibular pra Psicologia só que logo depois que eu terminei a inscrição... eu percebi que não era isso entendeu... porque tem toda aquela função... que os meus pais começaram que eu ia morrer de fo:::me... ser professo:::ra... sabe aquela história toda... (Acadêmico 19)

A categoria "Desejo de ser professor", quantitativamente, é a terceira categoria, agregando $21 \%$ das respostas dos ingressantes. Nessas respostas, os acadêmicos manifestam o desejo de ser professor, entretanto temos, tomando apenas os exemplos citados, diferenças de argumentação em cada uma delas.

No primeiro exemplo, o acadêmico (9), que sempre demonstrou o desejo de ser professor, inclusive por ter realizado o curso de magistério, faz referência às dificuldades de domínio de alguns tópios pertinentes à área: leitura e gramática.
Assim, o acadêmico quer ser professor, mas encontra dificuldades na realização do curso de Letras. Essas dificuldades são decorrentes das exigências do curso, embora, a acadêmica acreditava, antes de ingressar no curso, e por isso, o escolheu, que teria facilidade: "por que eu achei que eu fosse ter uma facilidade... agora até... até... eu mudei de opinião..”.

No segundo exemplo, o acadêmico (19) afirma que o desejo de ser professor (a) de português é desde que era criança. O interessante é que, ao contrário dos acadêmicos classificados na primeira categoria (Impossibilidade de ingressar no curso desejado), optou por Letras em detrimento de outro curso (Psicologia), demonstrando certeza em relação à decisão tomada. Esse acadêmico torna-se peculiar e significativo entre todos os alunos ouvidos, pois manifestou a certeza que queria ser professor de português, portanto tendo convicção que deveria fazer Letras. A fala desse acadêmico traz também outro aspecto interessante, pois, são apresentadas as vozes dos seus pais reforçando o senso comum (com justiça) em relação à principal dificuldade associada à profissão de professor: o desprestígio social que se manifesta na questão salarial: "porque tem toda aquela função... que os meus pais começaram que eu ia morrer de fo:::me... ser professo:::ra... sabe aquela história toda". Apesar de tudo isso, não desistiu.

A partir dos exemplos das categorias apresentadas, podemos afirmar que temos um grupo de acadêmicos de 
Letras com características peculiares. Entretanto, não podemos afirmar, porque seria uma postura leviana de nossa parte, que esse grupo é representativo do universo de acadêmicos de Letras. Agora, em função da experiência da docência nesse curso, podemos cogitar que o perfil do grupo é bem próximo das demais turmas, ao menos da mesma Instituição. Com isso, entendemos que temos um excelente material de análise para buscar traçar o conjunto de representações sobre o trabalho docente.

A seguir, apresentaremos uma classificação inicial das respostas dadas pelos acadêmicos à pergunta "O que é ser professor?”. Tal categorização, organizada a partir do agrupamento de respostas similares em termos do conteúdo temático, agrega também a análise das formas de agir mobilizadas nas falas dos acadêmicos, permitindo uma reflexão inicial com relação a possíveis representações do agir docente expressas pelos professores em formação.

\section{O que é ser professor?}

A partir das respostas dos acadêmicos do primeiro semestre do Curso de Letras à pergunta: "O que é ser professor?", percebemos que a maioria deles apontou como resposta: "Transmitir/Passar/ Compartilhar conhecimentos", havendo outras respostas como "Passar conteúdo e experiências", "Passar ensinamento/o que aprendeu" e "Facilitar o aprendizado".
Além dessas respostas, que caracterizam de alguma forma, o professor como aquele que tem como principal papel ensinar. Também, encontramos nos dados outros enfoques com relação ao fazer do professor. Por exemplo, um dos acadêmicos destacou, em sua resposta, a questão da disciplina como central: o professor seria aquele cujo papel seria o de disciplinador os alunos; outro acadêmico destacou a possibilidade de convivência com pessoas diferentes e de aprender a lidar com situações adversas, propiciada pelo ser professor; outro acadêmico destaca a dimensão política do ser professor, cujo papel principal seria: "resgatar o caráter político na juventude".

$\mathrm{Na}$ análise das respostas, consideramos intessante que alguns acadêmicos (6) apontaram que, além do papel de ensinar, devem ser aliados outros papéis à atividade do professor. Por exemplo, o professor deve ser amigo do aluno. Nos recortes a seguir, temos a descrição e a confirmação dessa concepção.

Exemplo 1:

$\mathrm{P}$ - e o que é ser professor pra ti?

A - ser professor pra mim... ai... é::... é::... ser um pouco de cada coisa... por que hoje em dia... eu não... eu não... eu não to julgando parâmetro assim... mas... o que eu vou fazer... eu não vou ser professora do século passado... do século que vem... não... eu sou professora agora... então o que eu tenho que fazer pra mim ser professora agora... tenho que ser um pouco de cada coisa... um pouco de mãe... um pouco de pai... um pouco de tia... um pouco de avó... um 
pouco de:: de:: de megera... então é ser um pouco de cada coisa... eu acho que começa tu gostando do que tu faz... por que no curso ali tu enxerga... que por mais que tu tenha sabedoria tu tem que saber passar pra atingi teu aluno... por que é o único jeito... se tu quer que ele aprenda... marca ele de algum jeito... chama a atenção dele... dá um jeito de:: de:: se esforça... ser professor é muita coisa... a pergunta é muito abrangente... (Acadêmico 9, grifo nosso)

Exemplo 2:

A - tu termina de educa tu tem que faze tudo pr/quase pelo aluno assim...

$\mathrm{P}$ - é uma responsabilidade muito grande né...

A - é uma responsabilidade muito grande... exatamente é como se fosse o pai mãe du/dum aluno (Acadêmico 19)

Conforme podemos observar, esses exemplos apontam para uma concepção de que o professor é como um faz-tudo. Assim, como tal deve ser "um pouco de cada coisa", como nos diz o Acadêmico 9. Essas respostas nos remetem para as considerações de Richter (2008) com relação ao problema da formabilidade, ou seja, em uma profissão como a docência, em função de sua não emancipação, a identidade profissional é frágil, de modo que "o estatuto do profissional é atravessado por paradoxos e ausência de um lugar simbólico específico a partir do qual exercer sua competência” (2008, p. 224).

Nesse sentido, é interessante observar que em apenas uma das respostas se faz referência ao fazer do professor como um "trabalho", havendo também, na fala desse sujeito, o emprego da palavra "profissão":

$P$ - e o que que tu acha que é ser professor?

A - ah um trabalho bem difícil né... isso eu concordo com quem me disse... e é uma/deve ser/eu acho ser uma profissão muito satisfatória né? por que sem o professor ninguém vai se formar... tem que ter um professor sempre né... ensino médio... ensino superior... mestrado... doutorado... (Acadêmico 14, grifo nosso)

Nessa fala, temos a caracterização do ser professor como um trabalho, uma profissão. Entretanto, não nos causa tanto estranhamento o fato de apenas esse acadêmico apresentar essa definição. Pelas pesquisas realizadas na área do trabalho docente, baseadas no ISD, de Bronckart e Machado, e nas Ciências do Trabalho, a dificuldade do reconhecimento do trabalho docente ser entendido como um trabalho é muito constante. Como referimos anteriormente, Bronckart afirma que há, em relação ao trabalho docente, uma opacidade e dificuldade de descrevê-lo, de falar sobre ele. Tudo isso deve ser decorrente da história da constituição da profissão professor que gera, até os nossos dias, a dificuldade de considerá-la um trabalho. Em função disso, ao descrevê-lo, predominam aspectos ligados às características pessoais do indivíduo (ser amigo, por exemplo) e não características do profissional. Conforme dados de pesquisa, com professores e com 
professores em formação, constatamos que ainda é recorrente a definição de ser professor como um sacerdócio.

Seguindo na análise, a partir dos elementos do trabalho/agir do professor tematizados nas respostas dos acadêmicos, verificamos, especialmente pela observação do funcionamento semântico dos verbos empregados, que, ao definir o que é ser professor, há predomínio do agir pluridimensional, sendo o agir físico o menos mobilizado. O quadro abaixo apresenta o percentual relativo a cada uma das figuras de agir colocadas em ação nas falas dos graduandos:

Quadro 3: Formas de agir mobilizadas nas respostas dos acadêmicos

\begin{tabular}{|l|c|}
\hline \multicolumn{1}{|c|}{ Agir tematizado } & Percentual \\
\hline Agir pluridimensional & $53,33 \%$ \\
Agir mental & $26,66 \%$ \\
Agir linguageiro & $6,66 \%$ \\
Agir afetivo & $5,72 \%$ \\
Agir com instrumentos & $4,77 \%$ \\
Agir físico & $2,86 \%$ \\
Total & $100 \%$ \\
\hline
\end{tabular}

No corpus analisado, o agir pluridimensional é marcado especialmente pelo emprego dos verbos "passar" (conhecimento), "transmitir" e "ensinar". Tais verbos denotam múltiplas dimensões do agir, por isso a classificação de pluridimensionais: "passar conhecimento", por exemplo, envolve, por parte do professor, no mínimo, a mobilização do agir mental e do agir linguageiro. No caso do agir mental, que ficou ranqueado em segundo lugar dentre as formas de agir tematizadas nas respostas dos acadêmicos, houve predomínio do verbo "aprender" (o professor não é aquele que ensina, mas também o que aprende, disseram os acadêmicos). $\mathrm{O}$ agir linguageiro foi tematizado nas falas principalmente por meio do verbo "explicar". O agir afetivo, por meio de "gostar". No caso do agir com instrumentos, houve predomínio dos de tipo simbólico e, quanto ao agir físico, foram verificadas apenas três ocorrências.

O predomínio do tipo de agir pluridimensional nas falas dos acadêmicos enfatiza o caráter multifacetado do trabalho do professor. Isso corrobora a afirmação de Machado (2007): o trabalho docente mobiliza o professor em seu ser integral. Cada ação do professor carrega diversos matizes, o que torna o trabalho docente altamente complexo.

Considerando o alto percentual de predicados que apontam para um agir mental e, em contrapartida ao o baixo índice da forma de agir com instrumentos, vemos que as qualidades intelectuais do professor são valorizadas pelos acadêmi$\cos$, em detrimento da sua capacidade de transformar artefatos em instrumentos em favor da mediação pedagógica. Aqui cabe retomar a definição construída por Machado (2007) para o trabalho docente. De acordo com a autora, o trabalho do professor envolve a criação de um meio que possibilite aos alunos a aprendizagem de conteúdos e o desenvolvimento 
de capacidades. Nesse ponto, parece interessante, no acompanhamento desses professores em formação, observar, nas coletas seguintes, em que medida as disciplinas de didática e práticas de ensino poderão mobilizar os acadêmicos para 0 emprego de instrumentos simbólicos e físicos na prática pedagógica.

\section{Considerações finais}

Neste artigo, apresentamos um breve apanhado sobre o Interacionismo Sociodiscursivo (ISD), especialmente no que tange às considerações teórico-metodológicas discutidas nessa corrente em relação ao trabalho docente. Na sequência, apresentamos também uma análise inicial dos dados referentes a uma das ações do projeto "Representações do Agir Docente".

Neste artigo, centramos a análise nas respostas apresentadas pelos alunos para duas perguntas pontuais apresentadas na entrevista de coleta de dados: "Por que escolheu o Curso de Letras?" e "O que é ser professor?". Em relação à primeira, buscamos traçar um perfil do grupo de alunos ingressantes no Curso de Letras. Em relação à segunda pergunta, propusemos uma análise das formas de agir mobilizadas nas falas dos acadêmicos, permitindo uma reflexão inicial com relação a possíveis representações do agir docente expressas por esses professores em formação.

Em relação ao projeto, a partir do quadro descrito, pretendemos continuar realizando entrevistas com os acadêmi$\cos$ - professores em formação -, a fim de verificarmos de que modo se constroem as representações em torno do "ser professor" na comunidade observada. Sendo o ISD uma corrente que proporciona, além da base teórica, um vasto aporte metodológico para a análise de textos, objetivamos, também, aprofundar nossas análises, atingindo, especialmente, o nível enunciativo, a fim de percebermos as diferentes vozes que são colocadas em cena no discurso dos sujeitos analisados, verificando se esses assumem a posição de professores, ou se ainda persiste a voz do aluno em seu dizer.

A nosso ver, compreender as representações do agir docente é fundamental, especialmente por que permite inclusive que se repense o modo de organização dos cursos de formação de professores. Tal preocupação aponta para o compromisso social da pesquisa acadêmica.

\section{Reflections on teaching work}

\section{Abstract}

This paper proposes a reflection on teaching work. Therefore, we assume that teaching is a job. Although it seem an obvious statement, researches on representations of teaching work show difficulties in defining this occupation, particularly in understanding it as a job. In this article, we present the foundations of Socio-Discursive Interactionism, which is the theoretical framework we use to analyze teaching work. This choice stems from the importance the theory gives to the study of the role of 
language practice in work situations, in this case, teaching. Finally, we present some data from the Project Representações do Agir docente, which aims to analyze the representations of the teaching act in texts related to the educational activity.

Keywords: Education as work. Teaching work. Socio-Discursive Interactionism.

\section{Referências}

AMIGUES, René. Trabalho do professor e trabalho de ensino. In: MACHADO, Anna Rachel (Org.). O ensino como trabalho. Uma abordagem discursiva. Londrina: Eduel, 2004. p. 35-53.

BAKHTIN, Mikhail. Marxismo e filosofia da linguagem. São Paulo: Educ, 1978.

BAKHTIN, Mikhail. Estética da criação verbal. São Paulo: Martins Fontes, 1992.

BARBOSA, Daniela. A imagem esfacelada do professor: um estudo em textos de revistas. 2009. 179 f. Tese (Doutorado em Linguística Aplicada e Estudos da Linguagem) - Programa de Estudos Pós-Graduados em Linguística Aplicada e Estudos da Linguagem, Pontifícia Universidade Católica de São Paulo, São Paulo, 2009.

BARRICELLI, Ermelinda. A reconfiguração pelos professores da proposta curricular da educação infantil. 2007. 323 f. Dissertação (Mestrado em Linguística Aplicada e Estudos da Linguagem) - Programa de Estudos Pós-Graduados em Linguística Aplicada e Estudos da Linguagem, Pontifícia Universidade Católica de São Paulo, São Paulo, 2007.

BRONCKART, Jean-Paul. Atividade de linguagem, textos e discursos: por um interacionismo sócio-discursivo. São Paulo: EDUC, 1999.
Atividade de linguagem, discurso e desenvolvimento humano. Campinas: Mercado de Letras, 2006.

CLOT, Yves. A função psicológica do trabalho. Petrópolis: Vozes, 2007.

. Trabalho e poder de agir. Belo Horizonte: Fabrefactum, 2010.

CORRÊA, Marcia Cristina; VEÇOSSI, Cristiano Egger. Representações do agir docente em textos de acadêmicos de um curso de licenciatura em letras. Letras, Santa Maria, v. 44, n. 1, p. 11-26, jun. 2012.

HABERMAS, Jürgen. Consciência Moral e Agir Comunicativo. Rio de Janeiro: Tempo Brasileiro, 1989.

MACHADO, Anna Rachel. Por uma concepção ampliada do trabalho do professor. In: GUIMARÃES, Ana Maria. de Mattos.; MACHADO, Anna Rachel; COUTINHO, Antónia. (Orgs.). O interacionismo sociodiscursivo: questões epistemológicas e metodológicas. Campinas: Mercado de Letras, 2007. p. 77-97.

MACHADO, Anna Rachel; BRONCKART, Jean-Paul. (Re-)configurações do trabalho do professor construídas nos e pelos textos: a perspectiva metodológica do grupo ALTER-LAEL. In: MACHADO, Anna Rachel et al (Orgs.). Linguagem e Educação: o trabalho do professor em uma nova perspectiva. Campinas: Mercado de Letras, 2009. p. 31-77.

MAZZILLO, Tânia. O trabalho do professor de língua estrangeira representado e avaliado em diários de aprendizagem. 2006. 189 f. Tese (Doutorado em Linguística Aplicada e Estudos da Linguagem) - Programa de Estudos Pós-Graduados em Linguística Aplicada e Estudos da Linguagem, Pontifícia Universidade Católica de São Paulo, São Paulo, 2006. 
MUNIZ-OLIVEIRA, Siderlene. O trabalho representado do professor de pós-graduação de uma universidade pública. 2011, Tese (Doutorado em Linguística Aplicada e Estudos da Linguagem) - Programa de Estudos Pós-Graduados em Linguística Aplicada e Estudos da Linguagem, Pontifícia Universidade Católica de São Paulo, São Paulo, 2011.

RICHTER, Marcos Gustavo. Aquisição, atividade e formabilidade. Letras. Santa Maria, v. 36, n. 1, p. 211-23, jun. 2008.

VIGOTSKI, Lev Semenovich. A construção do pensamento e da linguagem. São Paulo: Martins Fontes, 2001. 